обусловливает репрессивную роль права, которая в нелиберальный системе отношений раскрывается как его противоположность, то есть, по сути, - неправо.

Ключевые слова: право, правосознание, легизм, социальные связи и отношения, этатизм, традиционализм.

\title{
S. Ordenov
}

TRANSFORMATION OF LAW AND LEGAL CONSCIOUSNESS IN TRANSITIVE SOCIETIES IN GLOBALIZED WORLD

Introduction. The legal systems of different countries in a globalized world are unified by norms of international law. In this context the question arises: are countries integrating into the globalized community capable of ensuring the practical implementation of international legal obligations into their legal systems? It determines the aim and the tasks which are to define the key structural components causing the transformation of law and legal consciousness in transitive societies in a globalized world. Research methods are structural-functional, socio-cultural and comparative approaches in their dialectical unity. Research results: in our study we assume that the functions of law determine the existing type of society, which in turn influences the whole set of legal relations and is reflected in the manifestations of law and legal consciousness. Taken into account that in transitive societies, the transition to a liberal system of relations has not occurred, the functions of the legal mechanism become dysfunctional in nature, and the laws do not meet the criteria of justice. In such circumstances, dissimulation of law is rooting in the social space while support and production of fiction becomes the only one single possible sociality. Discussion. In transitive societies, a paternalistic mechanism of "securing" rights as privileges (Berman) is dominant. As a result, the rights are nullified, not reproduced at the level of being and, ultimately, do not reach the average citizen. On the grounds of impossibility of securing the law in the real life, the political and legal discourse of transitive societies affirms a manipulative component aimed at implanting the simulacra of the legal space. The very manipulation is used by the authorities as a mechanism for asserting non-law in the society. Conclusion. Despite the unification of the legal systems of different countries in accordance with the requirements of international law, people in most transitive societies of the traditionalist type continue to be trapped in the tribalism of interpersonal relationships. In such circumstances, the implementation of any legal ideas in the legislative system of the transitive countries becomes in practice prohibitive and repressive.

Keywords: law, legal consciousness, legism, social relations, etatism, traditionalism.

УДК 327:614

Т. А. Пода

\section{ВПЛИВ ІНФОРМАЦІЙНО-КОМУНІКАЦІЙНИХ ТЕХНОЛОГІЙ НА РОЗВИТОК ДЕМОКРАТІЇ}

\author{
Національний авіаційний університет; \\ podatetiana@nau.edu.ua; \\ Research ID: R-8153-2018; ORCID: 0000-0001-9662-1204
}

\begin{abstract}
Анотація. Здійснено аналіз впливу глобальних постіндустріальних комунікацій, які базуються на новітніх інформаційних технологіях, на демократію. Наголошується на тому, що в сучасному світі все частіше говорять про появу явища «електронної демократії», під якою розуміють відкритість, прозорість державної влади, підвищення ефрективності політичного врядування та активної участі громадян у прийнятті політичних рішень на основі використання інформаційно-комунікаційних технологій. Авторка також аналізує негативний бік поширення інфрормаційно-комунікаційних технологій, зокрема, наголошує, що інфрормація стає не тільки важливим фрактором розвитку: вона перетворюється на інструмент досягнення певних цілей, маніпуляцій, політичної нетерпимості.
\end{abstract}

Ключові слова: інформаційне суспільство, електронна демократія, електронний уряд, краудсорсінг.

\section{Вступ}

Говорячи про основні тенденції у розвитку сучасного суспільства, варто відмітити вплив інформаційних технологій, завдяки чому ми можемо говорити про концепцію інформаційного суспільства. Прийнято вважати, що термін «інформаційне суспільство» з'явився в 60-х роках XX століття. Вперше його було використано у працях японських дослідників Й. Масуди, Т. Сакайя. Як відомо, подальшого розвитку концепція набула у працях американських та європейських теоретиків: E Тоффрлера, 3. Бжезинського, Р. Коена, А. Турена, Ф. Уебстера, Е. Гідденса, Дж. Гелбрайта, М. Маклюена, які говорили про інфрормаційний розвиток суспільства як новий історичний етап цивілізації. До проблеми трансформації політичної влади в умовах інформаційного суспільства зверталися Е. Тофффлер, Т. Стоун'єр, О. Бард та Я. Зодерквіст. Питання демократизації суспільного життя в процесі формування інформаційного суспільства розглядалися у працях Й. Масуди, Д. Белла, Е. Тофрфлера та М. Кастельса. Серед українських учених, які зверталися до проблем інформаційного суспільства, можна згадати
В. Бебика, В. Цимбалюка, Ю. Петрухно та ін. Значення інфрормації та комунікації для демократичного суспільства вивчали Р. Бедрик, С. Матвієнків, Н. Ржевська та багато інших.

Перехід до інформаційного суспільства, який розпочався наприкінці XX-го - початку XXI століть, призвів до трансформації політичних інституцій. Це перетворення характеризується зміною ролі держави і появою нових структур, соціальних і політичних рухів, бізнес-груп та інших політичних акторів. Сучасна епоха ставить перед науковцями низку проблем, пов'язаних із процесом політичних і соціальних змін, що призводять до кризи класичної демократії. Пошук відповідей сприяв появі низки теоретичних концепцій, які сформулювали специфіку розвитку сучасного суспільства на основі використання інформаційно-комунікаційних технологій. Теорія постіндустріального суспільства Д. Белла була першою спробою зрозуміти сутність нового інформаційного простору та комунікаційних технологій як основних факторів переходу до нової форми демократії. Принципи функціонування інформаційного суспільства, які він сформулював, і сьогодні залишаються актуальними. У теорії «трьох 
хвиль» Е. Тоффрлера також робиться наголос на ролі інфрормаційно-комунікаційних технологій у процесі перетворення сфери політики, економіки та культури сучасного суспільства. Концепція «інформаційного суспільства» доповнюється теорією третьої хвилі С. Хантінгтона, якй аналізує основні тенденції сучасного світу - глобалізацію, інформатизацію та демократизацію як основні складові розвитку сучасного світу.

Отже, застосування традиційного розуміння демократії стає неможливим до суспільств, які існують і працюють у світі глобальних постіндустріальних комунікацій на основі застосування інформаційних технологій. У сучасному світі все частіше говорять про появу явища «електронної демократії», під якою розуміють відкритість, прозорість державної влади, підвищення ефективності політичного врядування та активної участі громадян у прийнятті політичних рішень на основі інфрормаційно-комунікаційні технології. Отже, «електронна демократія» діє як перспективна форма інтерактивної взаємодії громадськості та влади у політичних процесах сучасного світу.

Часто поняття «електронна демократія» ототожнюють із поняттям «електронний уряд», але ці поняття кардинально відрізняються за своїм змістом. На відміну від електронного уряду (еgovernment), який формується «згори» для більш ефективного функціонування державного апарату, електронна демократія (e-democracy) орієнтована на підвищення рівня участі громадян у політичному житті суспільства, тобто ініціатива йде «знизу».

Завдяки процесам інфоорматизації різко посилилися процеси взаємодії між різними політичними акторами, що перетворило світ на єдиний простір. Розвиток новітніх інформаційних технологій і глобальної комунікаційної мережі мали значний вплив на політичну сореру. Теорія і практика їхнього застосування в реалізації громадянських цінностей, реформуванні та трансформації політичних інститутів, що становлять державу, соціальні спільноти та окремих індивідів, свідчить про позитивний бік пристосування цих технологій до політичного життя, що виявляється як на глобальному, так i на національних рівнях (Ржевська, 2010). Проте розвиток новітніх інформаційних технологій не завжди сприяє утвердженню демократичних інститутів та консолідації різних країн, a, навпаки, часто призводить до відокремлення та посилення національної самосвідомості. Ці тенденції і пов'язані 3 ними конфлікти здійснюють істотний вплив на розвиток та перспективи демократії (як позитивні так і негативні) у сучасному політичному просторі, що актуалізує дослідження даної проблеми.

Зростання, поширення та запровадження інформаційних та телекомунікаційних технологій надають суспільству доступ до нових інструментів та методів, що сприяють зміні політичних інститутів демократії та створюють можливості для всіх членів суспільства впливати на своє життя. Це означає перетворення демократії на відкриту систему, що веде до утвердження плюралізму, нових цінностей, потреб, методів та процедур втілення. Розвиток web-технологій і мережевої взаємодії надають можливість громадянам брати участь у процесах державного управління. Ініціативи «мережевих громадян» стають ключовими при формуванні демократичних ініціатив, що базуються на використанні можливостей мережі Інтернет. Рух до інформаційного суспільства - це шлях до майбутнього людської цивілізації. Саме це записано в «Окінавській хартії глобального інформаційного суспільства»: «اнформаційно-комунікаційні технології $€$ одними з найважливіших чинників, що впливають на формування суспільства двадцять першого століття. Їхній революційний вплив торкається життя людей, освіти і роботи, а також взаємодії уряду і громадянського суспільства. Інформаційні технології швидко стають життєво важливим стимулом для розвитку світової економіки. Вони також надають можливість приватним особам, фрірмам і співтовариствам більш ефективно і творчо вирішувати економічні та соціальні проблемами. Перед усіма нами відкриваються величезні можливості» (Окінавська хартія глобального інформаційного суспільства, 2000).

Проте явище інформаційної демократії для України $€$ новим і недостатньо дослідженим. Сучасність ставить перед суспільством нові завдання та виклики, які полягають у використанні новітніх інформаційних технологій для побудови нового рівня демократичного суспільства. Тому вважаємо цю проблематику важливою для вивчення.

\section{Мета і завдання}

Мета статті полягає в дослідженні впливу інформаційних технологій на формування демократії.

Авторка ставить завдання виявити позитивні та негативні чинники впливу інформаційного суспільства на становлення електронної демократії та процеси прийняття рішень у політичній сорері; окреслити проблеми, які постають перед демократичними інституціями в епоху інформаційного суспільства.

\section{Методологія дослідження}

у статті використано загальнонаукові засоби: метод порівняльного аналізу, метод системного аналізу та діалектичний метод. При аналізі феномену електронної демократії авторка спирається на теорії демократії та інформаційного суспільства. Метод порівняльного аналізу застосовувався при аналізі демократії в сучасному суспільстві. Метод системного аналізу використовувався при інтерпретації концепцій інформаційного суспільства.

\section{Результати}

У світі вчені активно працюють над дослідженням основних тенденцій, що виникають у різних соціальних сфрерах під впливом інформатизації. Не є винятком і політична сфера. Звертаючись до визначення поняття «інформаційного суспільства», варто зазначити, що $€$ безліч варіантів визначення, наприклад, - це 
суспільство, орієнтоване на людей, відкрите для всіх і спрямоване на розвиток, в якому кожний може створювати інформацію і знання, мати до них доступ, користуватися і обмінюватися ними, сприяючи своєму сталому розвитку і підвищуючи якість свого суспільно-політичного життя. Існує багато ознак інформаційного суспільства, але усіх їх можна розділити на три основні групи. Перша - це свободний доступ будь-якої людини до будь-якої інформації; друга - це високий рівень розвитку інформаційно-комунікаційнтх технологій; третя група - це наявність розвиненої інформаційної інфраструктури суспільства. Тільки за таких умов суспільство можна вважати інформаційним (Петрухно, 2014: 130). Отже, завдяки новим інформаційним технологіям суспільство стає більш прозорим і разом із тим більш контрольованим. При переході до інформаційного суспільства радикальні зміни політичної системи обумовлені зміною моделі поводження громадян, їхньою переорієнтацією 3 матеріальних цінностей на цінності самореалізації (Коляденко, 2013).

Розвиток новітніх інформаційних технологій і глобальної комунікаційної мережі значною мірою позначається на політичній сорері. У сучасному інформаційному суспільстві ми все частіше чуємо про електронний формат політики, е-уряд, е-суди, е-кабінети. Поява «е-держави» дозволила спростити їі роботу: автоматизувати процеси та дати відкритий доступ до баз даних; з'явились нові способи контролю та відповідальності гілок влади перед громадянами. У сучасному науковому дискурсі інформаційна демократія розглядається як ідеальна гіпотетична модель політичної складової цифрової епохи, заснована на цінностях інформації в поєднанні із соціалізованими інформаційнокомунікаційними технологіями (Макаренко, 2013).

Термін «інформаційна демократія» запропонував фрранцузький політик і політолог М. Рокар, який вважає, що серцевиною демократії $€$ реальність взаємозв'язків між виборними особами, засобами масової інфрормації та виборцями. Новизна цієї форми демократії полягає в тому, що її складовими є загальне виборче право і вільний обіг інформації. У такому разі дотримується умова, що обидві сторони працюють чесно, без маніпуляцій і політичного обману (Митко). Тобто інформаційну демократію визначають як елітарний тип народовладдя, що має інтегральний характер високого рівня, спирається на інтелектуальний ресурс власних суб'єктів і об'єктів політики, передбачає ефективну організацію інтерактивної комунікації на всіх рівнях реалізації влади, а також може характеризуватися як харизматичний тип правління на основі використання інформаційнокомунікаційних технологій (Макаренко, 2013). Інформаційна демократія за сутністю процесу прийняття рішень має партисипаторний (демократія участі) та деліберативний (демократія обговорення) характер, що відкриває нові горизонти реалізації політики в будь-якій країні та в системі міжнародних відносин (Ржевська, 2010).

Але поряд із позитивними рисами поширення інформації і її впливу на демократичні процеси у суспільстві, варто вказати і на негативні тенденції. Інформація стає не тільки важливим фрактором розвитку, а вона перетворюється й на інструмент досягнення певних цілей у межах цілих суспільств. Колишній Генеральний Секретар $\mathrm{OOH}$, лауреат Нобелівської премії миру Кофрі Аннан зазначає, що «риторика ненависті, терористичні заклики, расові нападки та сексуальні домагання - для всього цього Інтернет став рідною домівкою - що в реальному світі може призвести до насильства» (Кофі Аннан).

Як слушно зауважує С. Орденов «превалювання у глобальному медіа-дискурсі однієї зі сторін медіалізації - маніпулятивної - викликає занепокоєння, адже руйнує в самій основі його комунікативну складову» (Орденов, 2017: 60). Але не можна не наголосити на тому, що розвиток Онлайн простору публічної політики шляхом розробки інформаційно-комунікаційних систем створює нові можливості для реалізації принципів «цифрової демократії», яка надає можливість громадянам і політичним акторам взаємодіяти при прийнятті та реалізації політичних рішень. «Цифрова демократія» знайшла свій практичне втілення в технологіях Web 2,0 та Web 3,0, які базуються на принципах відкритості прийняття політичних рішень на всіх рівнях (національному, регіональному, місцевому). Перехід інформаційних комунікаційних технологій на Web 2,0 сприяло розширенню взаємодії громадян на форумах, вебсайтах та медіа платформах. Кожен споживач інформації зараз сам виступає потенційним «медіа». Багато громадян беруть участь у політичних діях у режимі онлайн і усвідомлюють свою значущість. Сьогодні громадянин під впливом соціальних мереж усе більше стає «політичним споживачем» того, що йому подобається, ігноруючи неважливу, з його точки зору, інформацію.

Ми є свідками того, як у світовій практиці відбувається реалізація проекту gov 2,0 через створення ефективних комунікативних площадок між суспільством і владою; через інтеграцію державних структур і залучення посадових осіб до соціальних мережах і блогосфер; утворення спільнот, де державні структури взаємодіють із громадянами; створення блогів, де ведеться публічне обговорення проектів законів тощо.

У своїх попередніх розвідках ми вже писали про те, що «ефективність державного управління все частіше стає залежною від інформаційного забезпечення. Без інформації важко уявити політичне управління, розвиток політичної свідомості суспільства, взаємодію суб'єкта та об'єкта політики. ... Якщо система інформаційних зв'язків між державою, громадянським суспільство та особистістю добре розвинута, тоді керівні функції держави реалізуються 3 найбільшим потенціалом» (Пода, 2014: 70) Отже, наголошуючи на підвищенні ролі соціальних медіа та розвитку інформаційно-комунікаційних технологій в усіх сфрерах людського життя, які сприяють утворенню нових форм взаємодії між урядом і громадянами, варто згадати про один із таких видів взаємодії, як краудсорсінг. Термін «crowdsourcing» (crowd натовп і source - постачання; тобто - використання 
ресурсів) вперше запроваджений Джеффоом Хаві та Марком Робінсоном і був використаний для опису бізнес-моделі, яка базується на залученні звичайних споживачів, інтернет-користувачів і добровольців до вироблення і поширення товарів та послуг, без укладення трудового договору (Howe Jeff, 2009). Краудсорсінг дає змогу залучити широкі верстви населення 3 різними особистісними та професійними знаннями до фрормування банку ідей. 3 розвитком інформаційно-комунікаційних технологій це набуло масштабного характеру і забезпечило новий рівень вирішення проблем та завдань, що стоять перед державою і суспільством. Одним із найяскравіших прикладів краудсорсінгу $є$ створення Вікіпедії, де контент наповнюється звичайними користувачами Інтернету. Як ми зазначали раніше «комунікація у віртуальних соціальних мережах може бути сама по собі простором вербалізації політичного протесту, і одночасно така комунікація може спонукати індивідів до вчинення дій за межами соціальної мережі» (Пода, 2017: 69).

Особливістю використання

технології краудсорсінгу в політиці є те, що органи державної влади при визначенні ефективних управлінських практик, які б задовольняли потреби громадян, апелюють до користувачів Інтернету. Влада використовує краудсорсінг, розраховуючи на те, що громадянин безкоштовно поділиться своїми ідеями, виключно заради того, щоб побачити їх втіленими на практиці. Виділяють наступні види краудсорсінгової діяльності в публічній політиці:

- створення краудсорсінгових е-ресурсів умовах надзвичайних ситуацій;

- законотворчий краудсорсінг;

- співробітництво державних громадських об'єднань.

Отже, gov 2.0 передбачає не тільки надання громадянам послуг електронного врядування, а й залучення громадян до управління, формування зворотнього зв`язку і використання потенціалу «мережевого натовпу» («крауд-демократія») для вдосконалення урядових сервісів. Політичний краудсорсінг передбачає передачу деяких функцій «мережевим громадянам» та вирішення соціально значимих завдань фахівцями, які координують свою діяльність за допомогою мережевих технологій. У першу чергу, сюди потрапляють проекти обговорення різних законів та інших державних ініціатив. Зазвичай, обговорення проходять, як у режимі голосування, так і в режимі збору конкретних думок і пошуку рішень.

Аналізуючи практику використання краудсорсінгу, хочемо наголосити на тому, що у сорері публічної політики вона вирішує одночасно кілька важливих завдань. По-перше, сприяє консолідації та активній діяльності «мережевого громадянського суспільства» при вирішенні реальних соціальних проблем та завдань На думку Ю. Хабермаса, до основних характеристик мережевого громадянського суспільства належать «відкритість» як «створення широких, багатовимірних комунікаційних зв'язків», а також «спонтанність» - «вільне формування, плинність, постійна зміна структури» (Хабермас, 1995). Під впливом мережевих технологій відбувається формування відкритого простору, який надає нові можливості для розвитку громадянського суспільства, подолання ізольованості громадян, заангажованості органів державної влади, тощо.

Завдяки використанню краудсорсінгу у сфері публічної політики відбувається запровадження інновацій у систему політичного менеджменту. Тобто інструментарій соціальних мереж виступає системоутворюючою основою краудсорсінгу. Онлайн соціальні мережі стають організованими структурами в процесі прийняття політичних рішень, інструментами реалізації поставлених завдань. Краудсорсінг дає можливість членам соціальних мереж інтегруватися в експертний політичний простір, продукувати інноваційні проекти, модернізувати певні сфери життєдіяльності особистості.

\section{Обговорення}

Як бачимо, у сучасному світі головною силою інформації $€$ швидкість її поширення, яка значно перевищила швидкість іiї перевірки. Результатом цього стало зростання впливу будь-якої, навіть заздалегідь неправдивої, інфформації. Тепер немає значення правдивість, має значення оперативність. Поки інформація перевіряється, часто результату вже досягнуто. Ця нова якість інформаційного суспільства дозволяє активно маніпулювати масами, виборцями, скеровуючи їх не на пізнання правдивого стану справ, а тільки лишень на засвоєння певної інформації. На практиці це призводить до того, що державою керує не народ, а неофіційні органи влади, та інформація яку вони поширюють через соціальні медіа.

Ще М. Маклюен для визначення сутності сучасної комунікаційної ситуації, яка сформувалася в результаті поширення електронних засобів зв'язку, запропонував поняття «глобальне село». На його думку, електронні засоби комунікації відтворюють общину - глобальне село. М. Маклюен вважав, що люди стоять на порозі «розкутого i безтурботного» світу, в якому людство дійсно може стати єдиною сім'єю. Вступаючи в комунікацію один з одним шляхом електронних засобів зв'язку, люди міркують і вчиняють так, як ніби вони знаходяться зовсім поруч, живуть «в одному селі». Вони вільно або невільно все істотніше втручаються в життя одне одного, міркуючи про все, що їм доводиться бачити та чути. У глобальному селі повсякденно переплітаються і виставляються на загальний розгляд «усі часи і простори одразу» - усі «світогляди, культури, способи спілкування, цінності, традиції» (Маклюэн, 2003).

Один із провідних британських науковців, С. Коулман, досліджуючи питання фрормування простору для публічних дискусій в Інтернеті та вивчаючи ефрективність нових практик електронної демократії у глобальному масштабі, займаючись пошуком нових можливостей для покращення форм політичної участі громадян через Інтернет, з метою знаходження нових шляхів вдосконалення інституцій репрезентативної демократії за 
допомогою цифрових технологій, приходить до висновку, що «стрімкий розвиток цифрових технологій, не зміцнює демократію, як це зазвичай видається кібер-оптимістіам, а, навпаки, сприяє появі нового покоління людей, які добре орієнтується в технологіях, але зацікавлені не брати участі в політиці як демос, але більше заради маніпулювання безформною масою населення» (Коулман, 2018).

\section{Висновки}

Інформаційна трансформацію взаємодії між державою і громадянським суспільством, між урядом та органами управління з огляду на те, що сучасні інформаційно-комунікативні технології відкривають нові перспективи зовнішньої і внутрішньої політики, яка взаємодіє 3 громадянським суспільством, зокрема через мас-медіа, мережу Інтернет, соціальні медіа-платформи, інтерактивну комунікацію тощо. Разом із тим значна кількість дослідників відмічає очевидний негативний вплив інформаційно-комунікаційних технологій на демократію. Зокрема вони наголошують на маніпулятивних діях з боку владних та бізнес структур, на перекручуванні інформації або наданні неправдивої. Інтернет став домінуючою силою, коли мова йде про залучення коштів на виборчі кампанії, отримання доступу до інформації, обмін думками та дискусії, мобілізацію людей до політичної діяльності. Соціальні мережі, веб-сайти і твіти все частіше виступають як каналами політичної інформації, так і головною громадською ареною, де громадяни висловлюють свої ідей, залучають інших до протестних акцій, голосування або волонтерської роботи. Варто також зауважити, що сучасне покоління $є$ більш політично активним та терпимим, виявляє політичну обізнаність і толерантність, прагне до встановлення соціальної справедливості.

На нашу думку, дослідження інформаційної демократії $\epsilon$ перспективним і необхідним для українського суспільства та держави загалом. Саме на основі інфродемократії в державі можна побудувати відкриту політичну систему, зорієнтовану на вирішення проблем громадян, сорормувати зріле громадянське суспільство 3 освіченими та свідомими громадянами.

\section{Список літератури}

1. Ржевська Н. Вплив інформаційного суспільства на формування категоріального апарату політичної науки: інфрормаційна демократія як політична категорія / Н. Ржевська // Вісник Львів. ун-ту. Філософрсько-політологічні студії. - Вип. 1. - 2010.- C. 81-245.

2. Окінавська хартія глобального інформаційного суспільства. [Електронний ресурс]. - Режим доступу: https://zakon.rada.gov.ua/laws/show/998_163

3. Петрухно Ю. Є. Інформаційне суспільство: поняття, основні складові, характеристика / Ю. Є. Петрухно // Вісник Одеського національного університету: Серія «Бібліотекознавство. Бібліографознавство. Книгознавство». 2014. - Т. 19 (Вип. 1). - С. 127-133.

4. Коляденко В.А. Поняття «інформаційне суспільство» у класичних і сучасних концепціях / В.А. Коляденко // Український науковий журнал. Освіта регіону: політологія, психологія, комунікації. -2013 - № 2. - С. $11-19$.
5. Макаренко Є. А. Інформаційна демократія у стратегіях зовнішньої і внутрішньої політики республіки Польща / Є. А. Макаренко // Актуальні проблеми міжнародних відносин: зб. наук. пр. - К.: Київ. нац. ун-т ім. Т. Шевченка, Ін-т міжнар. відносин, 2013. - Вип. 17, - С. 3-9.

6. Митко А. Україна й інфрормаційна демократія: новий вимір політики [Електронний ресурс]. - Режим доступу: http://sena.lp.edu.ua:8080/bitstream/ntb/24515/1/14-77-81.pdf. Загол. з екрану.

7. Кофи Аннан Как информационные технологии угрожают демократии. О вопросах, ответы на которые определят будущее самой свободы. [Електронний ресурс]. Режим доступу: https://day.kyiv.ua/ru/article/media/kakinformacionnye-tehnologii-ugrozhayut-demokratii. Загол. з екрану.
8. Орденов C. C.
Медіалізаці
суспільної

правосвідомості у інформаційну добу / С. С. Ордєнов // Вісник Національного авіаційного університету. Сер.: Філософія. Культурологія: Збірник наукових праць. - Вип. 2 (26). - К.: HAY, 2017. - C. 58- 64.

9. Пода Т. Інформаційна війна як стратегія формування політичної свідомості (соціально-філософський аналіз) / Т.Пода // Вісник Національного авіаційного університету. Сер.: Філософрія. Культурологія: Збірник наукових праць. - Вип. 1 (19). - К.: НАУ, 2014. - С. 69- 73.

10. Howe Jeff. Crowdsourcing: Why the power of the crowd is driving the future of business / Jeff Howe. - Crown Business, $2009-336 \mathrm{p}$.

11. Пода Т. Вплив високих технологій на розвиток громадянського суспільства / Т. Пода // Вісник Національного авіаційного університету. Сер.: Філософрія. Культурологія: Збірник наукових праць. - Вип. 2 (26). - К.: НАУ, 2017. - С. 66-69.

12. Хабермас Ю. Демократия, разум, нравственность / Ю. Хабермас // Московские лекции и интервью. -, М.: Академия, 1995. - С. 245

13. Коулман С. Может ли интернет укрепить демократию. [Електронний ресурс]. - Режим доступу: https://bookz.ru/authors/stiven-koulman/mojet-li_332/1-mojetli_332.html. Загол. з екрану.

14. Маклюэн Г.М. Понимание Медиа: Внешние расширения человека / Г.М.Маклюэн. - М.: Жуковский: «КАНОН-пресс-Ц», «Кучково поле», 2003. - 464 с.

\section{References}

1. Rzhevs'ka, N. (2010). Vplyv informatsiynoho suspil'stva na formuvannya katehorial'noho aparatu politychnoyi nauky: informatsiyna demokratiya yak politychna katehoriya [Influence of the Information Society on the Formation of Categorical Apparatus of Political Science: Information Democracy as a Political Category] Visnyk L'vivskogo universytetutu. Filosofs'kopolitolohichni studiyi, Vyp. 1, 81-245 [in Ukrainian].

2. Okinavs'ka khartiya hlobal'noho informatsiynoho suspil'stva. [Okinawa Charter of the Global Information Society]. Retrieved from https://zakon.rada.gov.ua/laws/show/998_163 [in Ukrainian]

3. Petrukhno, Y. E. (2014). Informatsiyne suspil'stvo: ponyattya, osnovni skladovi, kharakterystyka [Information Society: Concepts, Main Components, Characteristics] Visnyk Odes'koho natsional'noho universytetu: Seriya "Bibliotekoznavstvo [in Ukrainian]

4. Kolyadenko, V.A. (2013). Ponyattya «informatsiyne suspil'stvo» u klasychnykh i suchasnykh kontseptsiyakh [The concept of "information society" in classical and modern concepts] Ukrayins'kyy naukovyy zhurnal. Osvita rehionu: politolohiya, psykholohiya, komunikatsiyi, № 2, 11-19 [in Ukrainian].

5. Makarenko, E.A. (2013). Informatsiyna demokratiya u stratehiyakh zovnishn'oyi i vnutrishn'oyi polityky respubliky Pol'shcha [Information Democracy in the Strategies of Foreign and Internal Policy of the Republic of Poland] Aktual'ni problemy mizhnarodnykh vidnosyn: zb. nauk. pr. Kyiv: Kyiv. nats. un-t im. T. Shevchenka, In-t mizhnar. vidnosyn, Vyp. 17, 3-9 [in Ukrainian].

6. Mytko, A. Ukraina i informatsiina demokratiya: novyy vymir polityky [Ukraine and Information Democracy: a New Dimension of Policy]. Retrieved from http:// sena. Ip.edu.ua:8080/bitstream/ntb/24515/1/14-77-81.pdf [in Ukrainian].

7. Kofi Annan Kak informatsionnyye tekhnologii ugrozhayut demokratii. $\mathrm{O}$ voprosakh, otvety na kotoryye opredelyat 
budushcheye samoy svobody [How information technology threatens democracy. About questions, the answers to which will determine the future of freedom itself]. Retrieved from https://day.kyiv.ua/ru/article/media/kak-informacionnye-tehnologiiugrozhayut-demokratii [in Russian].

8. Stiven Koulman Mozhet li internet ukrepit' demokratiyu [Can Internet Strengthen the Democracy]. Retrieved from https://bookz.ru/authors/stiven-koulman/mojet-li_332/1-mojet-

li_332.html [in Russian].

9. Ordenov, S. (2017). Medializatsi suspil'noyi pravosvidomosti $\mathrm{u}$ informatsiynu dobu [Medialization of Social Justice in the Information Age]. Visnyk Natsionalnoho aviatsiinoho universytetu, Proceedings of the National Aviation University, 2 (26), 58-64 [in Ukrainian].

10. Poda, T. (2014) Informatsiyna viyna yak stratehiya formuvannya politychnoyi svidomosti (sotsial'no-filosofs'kyy analiz) [Information war as a trategy for the Formation of Political Consciousness (Social and Philosophical Analysis)]. Visnyk
Natsionalnoho aviatsiinoho universytetu, Proceedings of the National Aviation University, 1 (9), 69-73. [In Ukrainian].

11. Howe, J. (2009) Crowdsourcing: Why the power of the crowd is driving the future of business. Crown Business.

12. Poda, T. (2017) Vplyv vysokykh tekhnolohiy na rozvytok hromadyans'koho suspil'stva [The Impact of High Technology on the Development of Civil Society]. Visnyk Natsionalnoho aviatsiinoho universytetu, Proceedings of the National Aviation University, 2 (26), 66-69 [in Ukrainian].

13. Khabermas, Yu. (1995) Demokratiya, razum, nravstvennost' [Democracy, reason, morality]. Moskovskiye lektsii $i$ interv'yu, Moscow lectures and interviews. Moscow: Akademiya, 245 [in Russian].

14. Maklyuen G. M. (2003). Ponimanie Media: Vneshnie rasshireniya cheloveka [Understanding Media: The Extensions of Man]. Moscow: Zhukovskij: «KANON-press-C», «Kuchkovo pole» [in Russian].

\section{Т. А. ПОДА}

\section{ВЛИЯНИЕ ИНФОРМАЦИОННО-КОММУНИКАЦИОННЫХ ТЕХНОЛОГИЙ НА РАЗВИТИЕ ДЕМОКРАТИИ}

В статье осуществляется анализ влияния глобальных постиндустриальных коммуникаций на демократию на основе новейших информационных технологий. Подчеркивается, что в современном мире все чаще говорят о появлении феномена «электронной демократии», под. которой понимается открытость государственной власти, повышение эфффективности политического управления и активное участие граждан в формировнии политических решений, на основаннии информационнокоммуникационных технологиях. Автор также анализирует негативную сторону распространения информационнокоммуникационных технологий, в частности, подчеркивает, что инфоормация становится не только важным фрактором развития, она превращается в инструмент достижения определенных целей, манипуляций, политической нетерпимости.

Ключевые слова: информационное общество, электронная демократия, электронное правительство, краудсорсинг.

\section{T. Poda}

\section{INFORMATION AND COMMUNICATION TECHNOLOGIES IMPACT ON THE DEVELOPMENT OF DEMOCRACY}

Introduction. The author made an attempt to analyze the impact of global post-industrial communications on democracy based on the latest information technologies. It is stressed that in the modern world they are increasingly talking about the emergence of the phenomenon of "e-democracy", which means openness, transparency of state power, increasing the efficiency of political governance and active participation of citizens in making political decisions based on information and communication technologies. It has also been analyzed the negative side of the dissemination of information and communication technologies, in particular the author stresses that the information becomes not only an important factor of development, it turns into an instrument for achieving certain goals, manipulation, political intolerance. The aim of the article is to study the impact of information technologies on the formation of democracy. The author poses the following tasks: to identify the positive and negative factors of influence of the information society on formation of e-democracy and decision-making processes in the political sphere; to outline problems faced by democratic institutions in the era of the information society. The research methodology of article cover general scientific approaches: benchmarking method, system analysis method and dialectical method. While analyzing the phenomenon of e-democracy, the author relied on the theory of democracy and the information society. Comparative analysis method is applied to the analysis of democracy in modern society. The system analysis method was used in interpreting the concepts of the information society. Research results. Information democracy predetermines the transformation of interaction between the state and civil society, between the government and the management bodies, given that modern information and communication technologies show new perspectives of foreign and Internal policies that interact with civil society, including mass media, Internet, social media platforms, interactive communications, etc. In particular, they emphasize manipulative actions on the part of the governmental and business structures, distortion of information or false. The internet has become the dominant force when it comes to raising funds for election campaigns, gaining access to information, exchanging views and discussions, mobilizing people for political activities. Conclusions. Social networks, websites and tweets are increasingly acting as a channel of political information as well as the main public arena, where citizens express their ideas, attract others to protest actions, vote or volunteer work. We can create an open political system, which is oriented on solving citizens' problems, forming civil society with educated and conscious citizens, only on the basis of information democracy. Keywords: information society, e-democracy, e-government, crowdsourcing. 